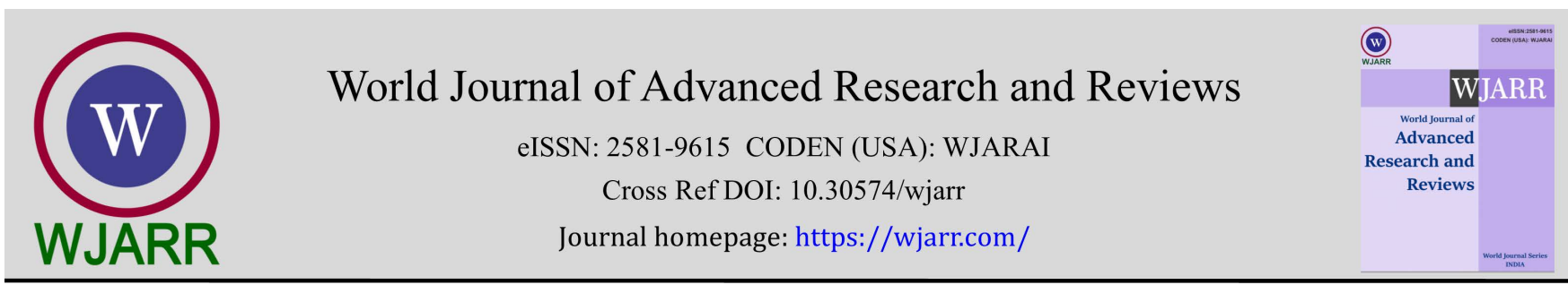

(RESEARCH ARTICLE)

\title{
Impact of 2-years practice of organic coffee farming on soil arthropod diversity
}

\author{
Mohammad Kanedi ${ }^{*}$, Suratman, Nismah Nukmal and Siti Ardiyanti \\ Department of Biology, Faculty of Math and Sciences, University of Lampung, Bandar Lampung, Indonesia.
}

World Journal of Advanced Research and Reviews, 2021, 10(01), 168-173

Publication history: Received on 04 March 2021; revised on 09 April 2021; accepted on 12 April 2021

Article DOI: https://doi.org/10.30574/wjarr.2021.10.1.0144

\begin{abstract}
Organic farming has been recommended by many experts in the world because of its positive ecological impacts such as increasing biodiversity. In Indonesia, the practice of organic farming is very widespread, including in smallholder coffee plantations. This study was intended to determine the impact of the organic farming system applied by smallholder coffee farmers for 2 years on soil arthropod diversity. On the two coffee farmlands, the conventional and organics (1 ha each), 10 plots of $5 \times 20$ meters were set and in each of these plots 5 sampling points were defined for collecting soil arthropods using pit-fall technique. The analysis of arthropod diversity in the two fields was quantified using the Shannon-Wiener diversity index model. The results showed that the two compared coffee farming systems had the same index of diversity ( $\mathrm{H}^{\prime}$ ) and evenness (E). However, statistical tests using the Hutcheson t-test revealed that the variance in diversity of arthropods in organic coffee farms was significantly higher than in conventional ones $(\alpha<0.001)$. Therefore, it can be concluded that the practice of organic coffee farming, although in a short time, has been able and potent to increase the population and/or diversity of soil animals.
\end{abstract}

Keywords: Conventional farming; Organic farming; Organic coffee plantation; Soil arthropods diversity

\section{Introduction}

In Indonesia, organic farming was only introduced in the first decade of the 21st century, but entering the second decade of organic farming developed very rapidly relying on grassroots initiatives [1]. The background for the development of organic farming systems in Indonesia is more or less the same as that in developed countries, namely the increasing demand for healthy organic food and increasing environmental concerns [2]. If in the beginning, organic farming was mostly applied to rice fields and horticulture, nowadays the organic system is also applied in smallholder coffee plantations [3].

From a food health point of view, organic agriculture has many benefits, but ecologically, this no-tillage farming system still leaves many questions. One of the key issues for organic farming is whether the application of this agricultural system in the long term and covering large areas of land provides greater benefits to biodiversity [4].

A study of the long-term impact of organic farming on coffee plantations compared to conventional ones found that organic systems in a long-term (12 years) improved soil properties, increased soil microbial and meso-fauna populations [5]. The question is whether the impact of organic coffee farming on biodiversity can only be known after decades, or can it be assessed in a shorter period? To determine the effect of organic coffee farming on soil biodiversity, we conducted a soil arthropod survey in organic coffee plantations that had only been implemented for 2 years.

${ }^{*}$ Corresponding author: Mohammad Kanedi

Department of Biology, Faculty of Math and Sciences, University of Lampung, Bandar Lampung, Indonesia.

Copyright (C) 2021 Author(s) retain the copyright of this article. This article is published under the terms of the Creative Commons Attribution Liscense 4.0. 


\section{Material and methods}

\subsection{Study site}

The organic and conventional coffee farms studied were smallholder plantations located an altitude of 497-525 meters above sea level in the Gedung Surian District (506' $44^{\prime \prime}$ S, $104^{\circ} 27^{\prime} 38^{\prime \prime E}$ ), West Lampung Regency, Lampung Province, Indonesia. The two coffee plantations compared in this study are intercropping plantations. In the conventional system, the existing intercrops are durian (Durio zibethinus), jackfruit (Artocarpus heterophyllus), cocoa (Theobroma cacao), citrus plants (Citrus spp.), Banana plants (Musa spp.) and pepper (Piper nigrum). Whereas in the organic coffee farmland, besides these plants, there is also a mimosoid tree (Leucaena leucocephala). In the organic system all soil management techniques have been abandoned and the fertilizers used were natural-organic materials such as compost and livestock manure. In contrast, on conventional coffee farms the synthetic pesticides, chemical fertilizers and mechanical equipments are still used in weeding the land.

\subsection{Sampling design}

Sampling design used in this study is a purposive sampling technique. The land area of the two types of plantations surveyed, conventional and organic, was \pm 1 ha each. On each of the 1 ha of coffee farmlands in question, 10 plots of $5 \mathrm{x}$ 20 meters were set. In each of these plots, there were 5 sampling points for trapping soil arthropods. With this design, on organic and conventional coffee farms, totally there were 50 sampling points each.

\subsection{Collecting the Arthropods}

In this study, the targeted soil animals were ground-dwelling arthropods. To collect them we used pitfall trapping technique, one of the most frequently used techniques for collecting ground-dwelling arthropods. The pitfall traps consisted of open plastic cups $(6 \mathrm{~cm}$ in diameter and $9 \mathrm{~cm}$ deep). The trap cups were buried into the ground until the rim of the cup is level with the ground. The cup is filled with a mixture of water and detergent and spiked with table salt as a preservative. Trapped animals were collected daily (24 hours after burial) and repeated for three days. The determination of arthropods is carried out to the Genera level using various reference books such as: Helmbergerand Wickings (2017), Borror et al. (1989), and Thomas (1990) [6-8].

\subsection{Data analysis}

The data analysis applied in the study followed the method introduced by Magurran (1988) [9], i.e. by analyzing the diversity of soil arthropods collected from each coffee farming system, conventional and organic, using Shannon-Wiener diversity index $\left(\mathrm{H}^{\prime}\right)$ and Evenness index (E). Next, variance in the diversity of the conventional and organic farmlands was estimated and the statistical differences between the two were compared using Hutcheson t-test. The formulas for determining these parameters are presented in Table 1.

Tabel 1 Ecological diversity parameters used in the data analysis of soil arthropods collected from conventional and organic coffee farmlands.

\begin{tabular}{|c|c|c|}
\hline Parameter & Formula & Score criteria \\
\hline $\begin{array}{l}\text { Shannon- } \\
\text { Wiener } \\
\text { diversity } \\
\text { index }\end{array}$ & $\begin{array}{l}\qquad \mathrm{H}^{\prime}=-\sum p i \ln p i \\
\text { Where: } \mathrm{H}^{\prime}=\text { Shannon diversity index at area } \\
\mathrm{p} i=(\mathrm{n} i / \mathrm{N}) \text { proportion of the } i \text {-th species } \\
\mathrm{n} i=\text { number of } i \text {-th species } \\
\mathrm{N}=\text { total number of individual } \\
\mathrm{ln}=\text { natural logarithm }\end{array}$ & $\begin{array}{l}<1.0=\text { Low diversity } \\
-3.22=\text { Moderate } \\
>3.22=\text { Highdiversity }\end{array}$ \\
\hline $\begin{array}{l}\text { Evenness } \\
\text { index }\end{array}$ & $\begin{array}{l}\qquad E=\frac{\mathrm{H}^{\prime}}{\ln \mathrm{S}} \\
\text { Where:E = evenness } \\
\mathrm{H}^{\prime}=\text { Shannon diversity index at area } \\
\mathrm{S}=\text { total number of species }\end{array}$ & $\begin{array}{l}<0.4=\text { low evenness } \\
0.4-0.6=\text { moderate evenness } \\
>0.6=\text { high evenness }\end{array}$ \\
\hline
\end{tabular}




\begin{tabular}{|c|c|c|}
\hline $\begin{array}{l}\text { Variance in } \\
\text { the diversity }\end{array}$ & $\begin{array}{l}\qquad \operatorname{Var} \mathrm{H}^{\prime}=\frac{\sum p i(\ln p i)^{2}-\left(\sum p i \ln p i\right)^{2}}{\mathrm{~N}}-\frac{\mathrm{S}-1}{2 \mathrm{~N}^{2}} \\
\text { The symbol description are the same as the previous } \\
\text { formula }\end{array}$ & $\begin{array}{l}\text { The lower the variance, the } \\
\text { higher the diversity }\end{array}$ \\
\hline $\begin{array}{l}\text { Hutcheson t- } \\
\text { test }\end{array}$ & $\begin{array}{l}\qquad t=\frac{\mathrm{H} 1^{\prime}-\mathrm{H} 2^{\prime}}{\sqrt[2]{\left.\operatorname{Var} \mathrm{H} 1^{\prime}+\mathrm{Var} \mathrm{H} 2^{\prime}\right)}} \\
\text { Where: } \mathrm{t}=\text { student } \mathrm{t} \text { test value; } \\
\text { other symbol description are the same as the } \\
\text { previous formula }\end{array}$ & $\begin{array}{l}\text { If } t_{\text {value }}>t_{(d f, 0.05)} \text { the diversity } \\
\text { of species in the two farmlands } \\
\text { is statistically different. }\end{array}$ \\
\hline $\begin{array}{l}\text { Degree of } \\
\text { freedom }\end{array}$ & $\begin{array}{l}\qquad \mathrm{df}=\frac{\left(\operatorname{Var~H}^{\prime}+\mathrm{Var} \mathrm{H}^{\prime}\right)^{2}}{\left[\left(\operatorname{Var} \mathrm{H} 1^{\prime}\right)^{2} / \mathrm{N} 1\right]+\left[\left(\operatorname{Var} \mathrm{H} 2^{\prime}\right)^{2} / \mathrm{N} 2\right]} \\
\text { Where: } d f=\text { requisite degree of freedom }(d f) \text { in } \\
\text { student t test; } \\
\text { other symbol description are the same as the } \\
\text { previous formula }\end{array}$ & $\begin{array}{l}\text { The higher the } d f \text { values, the } \\
\text { more representative the sample } \\
\text { size is. }\end{array}$ \\
\hline
\end{tabular}

\section{Results and discussion}

The broad picture of the diversity and population of the ground-dwelling arthropods our collected from two compared coffee farmlands, the conventional and organic, are presented in Table 2.The analysis of diversity, evenness, and variance in diversity of arthropods at the two coffee farms derived from the Shannon-Wiener diversity index model resulted in the values presented in Table 3. The results of statistical test using Student's t-test on variance in diversity between organic and conventional coffee farmlands are presented in Table 4. Based on the t-value (4.47007) which greatly exceeds the critical limit of the t-distribution with a $d f$ value of 2459 , as presented in Table 4 , it can be stated that the diversity index at the organic coffee farming system, significantly higher than that of conventional.

Table 2 Overall genera and individual numbers of soil arthropods collected from organic and conventional coffee farms.

\begin{tabular}{|l|l|l|l|l|}
\hline \multirow{2}{*}{ Genera } & \multirow{2}{*}{ Familia } & \multirow{2}{*}{ Ordo } & \multicolumn{2}{|l|}{ Coffee Farming System } \\
\cline { 4 - 5 } & & & Conventional & Organic \\
\hline Entomobrya & Entomobryidae & Collembola & 281 & 356 \\
\hline Corylophidae Genera & Corylophidae & Coleoptera & 249 & 326 \\
\hline Onychiurus & Onychiuridae & Collembola & 247 & 265 \\
\hline Cylisticus & Cylistidae & Isopoda & 119 & 138 \\
\hline Drosophilla & Drosophillidae & Diptera & 24 & 98 \\
\hline Formica & Formicidae & Hymenoptera & 17 & 82 \\
\hline Solenopsis & Formicidae & Hymenoptera & 18 & 68 \\
\hline Pheidole & Formicidae & Hymenoptera & 63 & 58 \\
\hline Phoridae Genera & Phoridae & Diptera & 12 & 25 \\
\hline Culex & Culicidae & Diptera & 11 & 24 \\
\hline Argas & Agasidae & Ixodida & 22 & 23 \\
\hline Lewisium & Corylophidae & Coleoptera & 3 & 19 \\
\hline Dermestez & Dermetidae & Coleoptera & 8 & 18 \\
\hline Anisolabis & Labiduridae & Dermaptera & 11 & 17 \\
\hline
\end{tabular}




\begin{tabular}{|l|l|l|l|l|}
\hline Dendroctomus & Scolytidae & Coleoptera & 17 & 16 \\
\hline Tridactylus & Tridactylidae & Orthoptera & 6 & 11 \\
\hline Lathrobium & Staphylinidae & Coleoptera & 7 & 9 \\
\hline Camponotus & Formicidae & Hymenoptera & 11 & 9 \\
\hline Minettia & Lauxaniidae & Diptera & 2 & 9 \\
\hline Ceraphron & Ceraphonidae & Hymenoptera & 7 & 8 \\
\hline Lestremia & Cecydomylidae & Diptera & 2 & 8 \\
\hline Dolichopus & Dolichopodidae & Diptera & 9 & 7 \\
\hline Acheta & Grylidae & Orthoptera & 8 & 7 \\
\hline Euchinetus & Eucinetidae & Coleoptera & 6 & 6 \\
\hline Scydmaenus & Scydmaenidae & Coleoptera & 1 & 6 \\
\hline Scydodes & Scytodidae & Araneae & 5 & 6 \\
\hline Liposcelis & Liposcelidae & Psocoptera & 3 & 6 \\
\hline Asaphes & Mymaridae & Hymenoptera & 3 & 5 \\
\hline Dysdera & Dysderidae & Araneae & 2 & 5 \\
\hline Chaoborus & Chaoboridae & Diptera & 3 & 4 \\
\hline Lepolepis & Lepidopsocidae & Psocoptera & 1 & 4 \\
\hline Blatella & Blattidae & Blattodea & 4 & 4 \\
\hline Total number of genera (S) & & 32 & 32 \\
\hline Total number of individuals (N) & & 1182 & 1647 \\
\hline
\end{tabular}

Table 3 The results of measurements of the ecological diversity of soil arthropods in conventional and organic coffee farms.

\begin{tabular}{|l|l|l|l|l|}
\hline \multirow{2}{*}{ Parameters } & \multicolumn{3}{|l|}{ Conventional system } & \multicolumn{2}{l|}{ Organic system } \\
\cline { 2 - 5 } & Values & Description & Values & Description \\
\hline Shannon-Wiener index $\left(\mathrm{H}^{\prime}\right)$ & 2.26694 & Moderate diversity & 2.47592 & Moderate diversity \\
\hline Evenness index $(\mathrm{E})$ & 0.65410 & High evenness & 0.71440 & High evenness \\
\hline Var $\mathrm{H}^{\prime}$ & 0.00133 & Diversity tends to be high & 0.00085 & Diversity tends to be high \\
\hline
\end{tabular}

Table 4 Statistical analysis result of the variance in the diversity between the two coffee farmlands.

\begin{tabular}{|l|l|l|l|}
\hline Statistic & Critical limit & Values & Description \\
\hline Hutcheson t-test & $\begin{array}{l}\text { t-distribution for } \\
\mathrm{df}>120 \text { at } \alpha<0.05= \\
1.960\end{array}$ & 4.47007 & $\begin{array}{l}\text { Variance in diversity between } \\
\text { conventional and organic coffee } \\
\text { farming is significantly different. }\end{array}$ \\
\hline Degree of freedom & $\mathrm{df}>120$ & 2459 & $\begin{array}{l}\text { Sampel size of arthropods in this study } \\
\text { is representative. }\end{array}$ \\
\hline
\end{tabular}


The data in Table 1 factually shows that the composition and population of soil arthropods living in the two coffee farms are relatively the same. The similarity in composition and population of the arthropods may indicate that the physical conditions of the soil on the two coffee farms are also still relatively the same. Collembola, Coleoptera, Isopoda, Diptera and Hymenoptera are the top five groups of arthropods found in this study. As revealed from various studies, it is known that the five arthropod orders mentioned can be used as bio-indicators of soil quality [10].

The similarity of soil arthropod diversity in the two coffee fields was also strengthened by the closeness in the ShannonWiener diversity index (Table 3). Both are at a moderate level, where in conventional system the value of $\mathrm{H}^{\prime}=2.26694$, while in organic one the value of $\mathrm{H}^{\prime}=2.47592$. As interpreted and acknowledged by many researchers, in the range 1.00 $<\mathrm{H}<3.22$, the diversity of species in a place is categorized as moderate [11].

Apart from similar diversity, the evenness of arthropod genera in the two coffee fields was also at the same level, namely $\mathrm{E}=0.65410$ in the conventional and $\mathrm{E}=0.71440$ in the organic fields. It suggests that the majority of the soil arthropods genera are evenly distributed in both farmlands surveyed [12].

Although in fact the diversity and evenness of soil arthropods on both coffee farms are the same, the variance in diversity of the two coffee farmlands, when estimated using Hutcheson t-test, are differ significantly $(\alpha<0.001)$. This t-test result clearly corresponds to the value of degrees of freedom $(d f=2459)$ which is far beyond the critical limit $(\mathrm{df}>120)$. The high $d f$-value statistically depict that the sample size of a study is very adequate [13].

As can be seen in Table 2 the total number of individual of soil arthropods found in organic coffee fields ( $\mathrm{N}=1647)$ is higher compared to conventional ones $(\mathrm{N}=1182)$. This fact should be used as a basis for assuming that the physical quality of organic coffee fields, even though it has only been implemented for 2 years, has improved. No-tillage practices and the use of compost and manure have long been known to maintain soil structure that encourages populations of beneficial soil fauna [14].

\section{Conclusion}

Based on the descriptive data and the results of quantitative analysis of the diversity of arthropod genera obtained in this study, it can be concluded that the practice of organic coffee farming, although in a short time, has been able to increase the population and/or diversity of soil animals.

\section{Compliance with ethical standards}

\section{Acknowledgments}

We sincerely thank the smallholder coffee plantation owners for their permission and support for this research.

\section{Disclosure of conflict of interest}

The authors declare no conflict of interests.

\section{References}

[1] Reuter T, MacRae G. Regaining Lost Ground: A Social Movement for Sustainable Food Systems in Java, Indonesia, Anthropology of food [Online], Articles VARIA, Online since 18 July 2019, connection on 29 March 2021.

[2] Hansen B, Alrøe HF, Kristensen ES. Approaches to assess the environmental impact of organic farming with particular regard to Denmark. Agriculture, Ecosystems and Environment. 2001; 83: 11-26.

[3] David W, Ardiansyah. Organic agriculture in Indonesia: challenges and opportunities. Organic Agriculture. 2017; 7(3):329-338.

[4] Hole DG, Perkins AJ, Wilson JD, Alexander IH, Grice PV, Evans AD. Does organic farming benefit biodiversity? Biological Conservation. 2005; 122: 113-130.

[5] Velmourougane K. Impact of Organic and Conventional Systems of Coffee Farming on Soil Properties and Culturable Microbial Diversity, Scientifica. Article ID 3604026. 2016; 9.

[6] Helmberger M, Wickings K. The Soil Animals Handbooks. Cornell University. 
[7] Borror DJ, Triplehorn CA, Johnson NF. An introduction to the study of insects. 6th edition. Saunders College Publishing, Philadelphia. 1989; 875.

[8] Thomas DC. Introduction to Arthropods: The Real Rulers of the Earth. Mc Graw-Hill. Publishers, London. 1990; 237-250.

[9] Magurran AE. Ecological diversity and its measurement (1st Ed). Chapman and Hall, London. 1988; 179.

[10] Nsengimana V, Kaplin BA, Francis F, Nsabimana D. Use of soil and litter arthropods as biological indicators of soil quality in forest plantations and agricultural lands: A Review. Entomologie Faunistique - Faunistic Entomology. 2018; 71.

[11] Kanieski MR, Longhi SJ, Soares PRC. Methods for Biodiversity Assessment: Case Study in an Area of Atlantic Forest in Southern Brazil. Additional information is available at the end of the chapter. 2017.

[12] Jost L. The Relation between Evenness and Diversity. Diversity. 2010; 2: 207-232.

[13] Kasseney BD, N'tie TB, Nuto Y, Wouter D, Yeo K, Glitho IA. Diversity of Ants and Termites of the Botanical Garden of the University of Lomé, Togo. Insects. 2019; 10: 218.

[14] Arden-Clarke C, Hodges RD. The Environmental Effects of Conventional and Organic/Biological Farming systems. II. Soil Ecology, Soil Fertility and Nutrient Cycles, Biological Agriculture \& Horticulture. 1988; 5(3): 223-287. 